\title{
Correlation between Depression Severity and Thiol Disulfide Homeostasis in Patients undergoing Hemodialysis
}

\author{
Hüseyin Kurku ${ }^{1}$, Yavuz Turgut Gederet ${ }^{1}$, Mehmet Akif Bor ${ }^{1}$, Ibrahim Güney², Salim Neşelioğlu and Zeynep \\ Biyik $^{4}$ \\ ${ }^{1}$ Department of Biochemistry, University of Health Sciences, Konya Health Application and Research Center, Konya, Turkey \\ ${ }^{2}$ Department of Nephrology, University of Health Sciences, Konya Health Application and Research Center, Konya, Turkey \\ ${ }^{3}$ Department of Biochemistry, Faculty of Medicine, Yildirim Beyazit University, Ankara, Turkey \\ ${ }^{4}$ Department of Internal Medicine, Selcuk University Faculty of Medicine, Konya, Turkey
}

\begin{abstract}
Objective: To investigate the correlation between depression severity and oxidative stress in patients undergoing hemodialysis (HD) using thiol disulfide homeostasis (TDH).

Study Design: Descriptive, analytical study.

Place and Duration of Study: Konya Health Application and Research Center, Konya, Turkey from September 2019 to March 2020.

Methodology: A total of 67 patients including 35 males (52.2\%) and 32 females (47.8\%), receiving HD treatment, were included in the study. The Hamilton depression rating scale (HAM-D) was applied to the participants. Thiol disulfide homeostasis (total thiol (TT), native thiol (NT), disulfide, disulfide/NT ratio, disulfide/TT ratio, and NT/TT ratio) parameters, albumin, and ischemia modified albumin (IMA) levels were determined. The study groups were investigated by dividing them into groups according to their gender and HAM-D score.

Results: According to HAM-D score, there were $32(47.8 \%)$ patients with depression symptom (DS, HAM-D score of $\geq 8$ ) and $35(52.2 \%)$ patients without DS (HAM-D score: $0-7$ ). Modified Charlson comorbidity index (MCCI), disulfide, disulfide/NT\%, and disulfide/TT\% levels were statistically and significantly higher and NT/TT\% was statistically and significantly lower in DS group than the values of the groups without $D S(p=0.003, p=0.043, p=0.017, p=0.017$ and $p=0.017$, respectively). HAM-D score and $\mathrm{MCCl}$ were statistically and significantly higher in females than males ( $<<0.001, p=0.001$, respectively). While, 21 patients $(65.6 \%)$ had DS in women; according to HAM-D score, this rate was found to be statistically higher than men (11 patients, 31.4\%, $p=0.005)$.

Conclusion: Almost half of HD patients had at least moderate depression symptoms. In the group of HD patients with DS, TDH shifted in the oxidative direction. This may contribute to the future studies in enlightening depression etiology in HD patients.
\end{abstract}

Key Words: Hemodialysis, Depression, Thiol disulfide homeostasis (TDH), IMA.

How to cite this article: Kurku H, Gederet YT, Bor MA, Güney I, Neşelioğlu S, Biyik Z. Correlation between Depression Severity and Thiol Disulfide Homeostasis in Patients undergoing Hemodialysis. J Coll Physicians Surg Pak 2020; 30(12):1273-1278 .

\section{INTRODUCTION}

End-stage renal disease (ESRD) is a chronic disease with treatment option that is usually life-long dialysis or kidney transplant. ${ }^{1}$ The most common comorbid psychiatric disease of ESRD patients is depression.

Correspondence to: Dr. Hüseyin Kurku, Department of Biochemistry, University of Health Sciences, Konya Health Application and Research Center, Konya, Turkey E-mail: hkurku@gmail.com

Received: October 21, 2020; Revised: November 13, 2020; Accepted: December 05, 2020

DOI: https://doi.org/10.29271/jcpsp.2020.12.1273
One of the most important mortality determinants in dialysis patients is depression in systemic review and meta-analysis. However, depression etiology in dialysis patients is still not fully clarified. Depression can occur as a primary disease or it can also be seen as secondary to many psychiatric and medical conditions. $^{2}$

The patient receiving dialysis treatment faces with many stresses and his/her quality of life is generally poor. The most important psychological stress factors in these patients can be regarded as dependent on device, long-term dialysis sessions, diet, loss of functionality, sexual dysfunction, disease-treatment effects and fear of death. The cause for poor quality of life may bethe associated depression. ${ }^{3}$ 
The situation between production and elimination of free radical is known as the oxidative balance. Preserving oxidative balance in favour of antioxidants limits the damage caused by free radicals in the organism. Along with cysteine, homocysteine, glutathione, and albumin, thiol groups of certain proteins constitute the plasma thiol pool. Thiols are an important antioxidant and play a key role in the limitation of reactive oxygen radicals by the enzymatic and non-enyzmatic pathways. Thiol disulfide homeostasis (TDH) is necessary for the regulation of detoxification, apoptosis, signal pathways and enzymatic reactions. Abnormal dynamic TDH has been shown in diabetes, cancer, cardiovascular diseases and many more chronic pathological conditions. ${ }^{4}$

In literature, there are studies investigating oxidative stress or depression level in HD patients. However, there is no study investigating the correlation between depression severity and TDH and oxidative stress in this group. The authors believe that dialysis treatment, which affects life in every aspect, will disrupt TDH and increase depression symptoms. Hamilton depression rating scale (HAM-D), developed by Hamilton et al., is widely used to determine severity of symptoms in depressive patients. Its Turkish validity and reliability study was conducted by Akdemir et al. This scale was designed with 17 questions and maximum 53 points. According to the score obtained from the scale, scores less than 8 refers to normal, scores between 8-16 points refer to mild to moderate depression, 17 and higher scores indicate that patients show major depression symptoms. ${ }^{5}$

The aim of this study was to investigate the correlation between depression severity and oxidative stress by using dynamic TDH in HD patients. So, this study is likely to contribute to the etiology of dialysis-depression correlation, the cause of which has not been fully clarified.

\section{METHODOLOGY}

This study was conducted at Konya Health Application and Research Center, Konya, Turkey from September 2019 to March 2020. Patients receiving HD treatment for at least three months, three days a week and four hours a day in hemodialysis unit due to ESRD, were included in this study. The participants were informed about the study, informed consent form was signed, and thus they were included in the study. Detailed anamnesis and physical examinations of all participants were performed and Hamilton depression rating scale (HAM-D) was applied. All information of the sample group (age, gender, laboratory tests, radiological tests etc.) were taken from the patient file. Body mass index (BMI) was calculated as body weight/height ${ }^{2}\left(\mathrm{~kg} / \mathrm{m}^{2}\right)$. In order to evaluate dialysis adequacy, $\mathrm{Kt} / \mathrm{V}$ (Kt=Total cleaned plasma volume / $\mathrm{V}=$ Distribution volume) was calculated and recorded. The patients were scanned for chronic diseases and modified Charlson comorbidity index $(\mathrm{MCCl})$ was calculated for all participants. ${ }^{6}$ As per exclusion criteria of the study, patients who were hospitalised for any reason, had a psychiatric diagnosis or took any psychiatric medication, suffering from dementia and under 18 years of age, were not included in the study. For the study, Ethics Committee approval was obtained from Selcuk University Faculty of Medicine (26/09/2018 dated, 2018/321 numbered).

Five $\mathrm{mL}$ venous blood samples were taken into routine biochemistry tubes (gel, vacuum). The samples were centrifuged at $3000 \mathrm{~g}$ for 10 minutes and their supernatants were separated. The separated serum samples were stored at $-80^{\circ} \mathrm{C}$ until the study day. In the study day, the samples were solved and all samples were studied on the same day. Thiol disulfide homeostasis (total thiol (TT), native thiol (NT), disulfide, disulfide/NT ratio, disulfide/TT ratio, NT/TT ratio) parameters, albumin, and ischemia modified albumin (IMA) levels were examined in the samples.

TT and NT levels were studied in the serums of the patients in the biochemistry autoanalyser with the method developed by Erel and Neselioglu (Cobas 501; Roche Diagnostics, Indianapolis, Ind). Dynamic disulfide bonds were separated from functional thiol groups using sodium borohydride ( $\mathrm{NaBH} 4$ ). Unused $\mathrm{NaBH} 4$ in the medium was removed by the addition of formaldehyde. By this way, the formation of disulfide bonds after the use of 5 , 5 '-dithiobis-2-nitrobenzoic acid (DTNB) was reduced. TT level was calculated by modified Ellman method. The half of the difference between serum TT and NT were defined as disulfide level. Disulfide/NT, disulfide/TT, and NT/TT ratios were calculated by using these data. Results are given in $\mu \mathrm{mol} / \mathrm{L}$ and $\%{ }^{7}$

Serum albumin level was measured with albumin commercial kit, (Beckman Coulter Inc., Brea, CA) Olympus AU 400 (Olympus Life \& Material Science Europe, Hamburg, Germany) autoanalyser. Serum IMA levels were determined by albumin cobalt binding test, a rapid colorimetric method developed by Bar-Or et al. IMA Albumin ratio (IMA/AlbR\%= IMA/Alb*100) was calculated in percent. ${ }^{8}$

For the data assessment, SPSS version 25 (IBM Corp. released 2017 was used. IBM SPSS Statistics for Windows, Version 25.0. Armonk, NY: IBM Corp.) statistical package programme was used. After checking the prerequisites of variables, normality and the homogeneity of variances (Shapiro-Wilk and Levene Test), were evaluated. While conducting data analysis, the differences between two dependent groups were evaluated with independent samples test when the parametric test prerequisites were compared; if not, then they were evaluated with Mann-Whitney U-test. For the variables, mean \pm standard deviation and median (Interquartile Range IQR: 25th percentile-75th percentile), percentage and frequency values were used. In correlation analysis, Pearson's correlation analysis was made for the testsmeeting parametric prerequisites; and Spearman's correlation analysis was made for non-parametric tests. For the significance level of the tests, $p<0.05$ value was accepted.

\section{RESULTS}

A total of $67 \mathrm{HD}$ patients, who were in the age range of 18-85 years and had a mean age of $53.7 \pm 16.8$ yearsCÇ, were included in the study. 
Table I: Comparison of demographic characteristics and variables of the study group based on gender.

\begin{tabular}{|c|c|c|c|c|}
\hline Variables & $\begin{array}{l}\text { Female } \\
(n: 32 \text {, } \\
\mathbf{4 7 . 8 \% )}\end{array}$ & $\begin{array}{c}\text { Male } \\
\text { (n:35, 52.2\%) }\end{array}$ & $\begin{array}{c}\text { Total } \\
\text { (n:67, 100\%) }\end{array}$ & $\begin{array}{c}\text { p- } \\
\text { value }\end{array}$ \\
\hline Age (years)* & $\begin{array}{c}57.69 \\
( \pm 16.37)\end{array}$ & $50.06( \pm 16.66)$ & $53.70( \pm 16.84)$ & $0.063^{*}$ \\
\hline BMI $\left(\mathrm{kg} / \mathrm{m}^{2}\right)^{*}$ & $26.38( \pm 5.62)$ & $24.58( \pm 4.44)$ & $25.44( \pm 5.08)$ & $0.149^{*}$ \\
\hline $\begin{array}{l}\text { Dialysis time } \\
\text { (month) }^{\#}\end{array}$ & $\begin{array}{c}42.57 \\
(28.80-103.43) \\
\end{array}$ & $30.40(12.17-79.10)$ & $36.00(18.20-84.00)$ & $0.128^{\mathrm{C}}$ \\
\hline $\mathrm{Kt} / \mathrm{V}^{\#}$ & $\begin{array}{c}1.74 \\
(1.54-1.88)^{\alpha} \\
\end{array}$ & $1.52(1.28-1.60)$ & $1.60(1.32-1.76)$ & $<0.001^{\mathrm{C}}$ \\
\hline HAM-D score ${ }^{\#}$ & $\underset{\alpha}{10.0(6.3-17.8)}$ & $4.0(2.0-11.0)$ & $7.0(4.0-15.0)$ & $<0.001^{C}$ \\
\hline $\mathrm{MCCl}^{\#}$ & $6.0(5.0-8.8)^{\alpha}$ & $4.0(3.0-6.0)$ & $5.00(3.0-7.0)$ & $0.001^{\mathrm{C}}$ \\
\hline $\begin{array}{l}\text { Creatinine } \\
(\mathrm{mg} / \mathrm{dL}) *\end{array}$ & $6.93( \pm 1.53)^{\alpha}$ & $8.37( \pm 2.73)$ & $7.69( \pm 2.33)$ & $0.011^{*}$ \\
\hline $\begin{array}{l}\text { Total } \\
\text { cholesterol } \\
(\mathrm{mg} / \mathrm{dL})^{\#}\end{array}$ & $172(144-188)$ & $149(135-180)$ & $159(136-185)$ & $0.099^{\mathrm{C}}$ \\
\hline $\begin{array}{l}\text { BUN predialysis } \\
(\mathrm{mg} / \mathrm{dL})^{*}\end{array}$ & $58.21( \pm 12.8)$ & $64.93( \pm 16.68)$ & $61.71( \pm 15.22)$ & $0.071^{*}$ \\
\hline $\begin{array}{l}\text { Hemoglobin } \\
(\mathrm{g} / \mathrm{dL})^{*}\end{array}$ & $11.13( \pm 1.25)$ & $11.37( \pm 1.08)$ & $11.26( \pm 1.16)$ & $0.395^{*}$ \\
\hline Albumin $(\mathrm{g} / \mathrm{dL})^{*}$ & $3.13( \pm 0.85)$ & $3.15( \pm 0.86)$ & $3.14( \pm 0.85)$ & $0.918^{*}$ \\
\hline IMA $(\mathrm{ABSU})^{\#}$ & $\begin{array}{c}0.85 \\
(0.77-0.96)\end{array}$ & $0.82(0.76-0.86)$ & $0.82(0.77-0.94)$ & $0.119^{\mathrm{C}}$ \\
\hline IMA/AlbR (\%) $)^{\#}$ & $\begin{array}{c}27.61 \\
(22.97-32.94)\end{array}$ & $25.45(20.76-31.60)$ & $26.17(20.97-32.77)$ & $0.422^{\mathrm{C}}$ \\
\hline $\begin{array}{l}\text { Native thiol } \\
(\mu \mathrm{mol} / \mathrm{L}) \mathrm{NT}^{*}\end{array}$ & $311.3( \pm 49.8)$ & $296.6( \pm 59.6)$ & $303.6( \pm 55.22)$ & $0.280^{*}$ \\
\hline $\begin{array}{l}\text { Total thiol } \\
(\mu \mathrm{mol} / \mathrm{L})^{*}\end{array}$ & $345.4( \pm 52.3)$ & $329.6( \pm 63.4)$ & $337.17( \pm 58.45)$ & $0.272^{*}$ \\
\hline $\begin{array}{l}\text { Disulfide } \\
(\mu \mathrm{mol} / \mathrm{L})\end{array}$ & $\begin{array}{c}17.30 \\
(14.55-19.75)\end{array}$ & $17.00(12.85-19.05)$ & $17.15(13.40-19.60)$ & $0.383^{\mathrm{C}}$ \\
\hline $\begin{array}{l}\text { Disulfide/native } \\
\text { thiol }(\%)^{*}\end{array}$ & $5.60( \pm 1.78)$ & $5.70( \pm 2.53)$ & $5.65( \pm 2.19)$ & $0.849^{*}$ \\
\hline $\begin{array}{l}\text { Disulfide/total } \\
\text { thiol }(\%)^{*}\end{array}$ & $4.99( \pm 1.46)$ & $5.03( \pm 2.00)$ & $5.01( \pm 1.75)$ & $0.923^{*}$ \\
\hline $\begin{array}{l}\text { Native } \\
\text { thiol/total thiol } \\
(\%)^{*}\end{array}$ & $90.0( \pm 2.9)$ & $89.9( \pm 3.99)$ & $89.98( \pm 3.45)$ & $0.924^{*}$ \\
\hline \multicolumn{4}{|c|}{ Education (under/graduate) } & $0.420^{\S}$ \\
\hline $\begin{array}{l}\text { Undergraduate, } \\
\mathrm{n}(\%)\end{array}$ & $17(53.1)$ & $22(62.9)$ & $39(58.2)$ & \\
\hline $\begin{array}{l}\text { Graduate, } \mathrm{n} \\
(\%)\end{array}$ & $15(46.9)$ & $13(37.1)$ & $28(41.8)$ & \\
\hline \multicolumn{4}{|c|}{ Status (not married/married) ${ }^{\alpha}$} & $0.019^{\S}$ \\
\hline $\begin{array}{l}\text { not married, } n \\
(\%)\end{array}$ & $15(46.9)$ & $7(20)$ & $22(32.8)$ & \\
\hline married, n (\%) & $17(53.1)$ & $28(80)$ & $45(67.2)$ & \\
\hline \multicolumn{4}{|l|}{ DM (no/yes) } & $0.191^{\S}$ \\
\hline No, n (\%) & $20(62.5)$ & $27(77.1)$ & $47(70.1)$ & \\
\hline Yes, n (\%) & 12 (37.5) & $8(22.9)$ & $20(29.9)$ & \\
\hline \multicolumn{4}{|l|}{ HT (no/yes) } & $0.770^{\varsigma}$ \\
\hline No, n (\%) & $19(59.4)$ & $22(62.9)$ & $41(61.2)$ & \\
\hline Yes, n (\%) & $13(40.6)$ & $13(37.1)$ & $26(38.8)$ & \\
\hline \multicolumn{4}{|l|}{ DS (no/yes) ${ }^{\alpha}$} & $0.005^{\S}$ \\
\hline No, $n(\%)$ & $11(34.4)$ & $24(68.6)$ & $35(52.2)$ & \\
\hline Yes, n (\%) & $21(65.6)$ & $11(31.4)$ & $32(47.8)$ & \\
\hline \multicolumn{5}{|c|}{$\begin{array}{l}\text { *Values are given as mean }( \pm s d),{ }^{*} \text { Values are given as Median }(I Q R: 25 \text { th } \\
\text { percentile-75th percentile), }{ }^{*} p \text {-value for Independent Samples Test. }{ }^{C} p \text {-value for } \\
\text { Mann-Whitney U Test, }{ }^{s} p \text {-value for Chi-square Test }{ }^{\alpha} \text { Statistically significantly } \\
\text { different from the male group, sd:Std. Deviation, IQR: Interquartile Rang. }\end{array}$} \\
\hline
\end{tabular}

Thirty-two of them were females and had a mean age of $57.7 \pm$ 16.4 years; 35 (52.2\%) were males and had a mean age of 50.1 \pm 16.7 years. When the sample group was divided in terms of gender, no statistically significant difference was found in the age, BMI, dialysis duration, total cholesterol, blood urea nitrogen (BUN) before dialysis, hemoglobin level, Albumin, IMA, IMA/AlbR, TDH, education level, and accompanying DM and HT frequency.
Table II: Comparison of demographic characteristics and variables of the study groups based on the presence of depression symptoms.

\begin{tabular}{|c|c|c|c|}
\hline Variables & $\begin{array}{l}\text { Non-depressive } \\
\text { symptom } \\
\text { (HAM-D score 0-7) } \\
\text { (n:32, 47.8\%) }\end{array}$ & $\begin{array}{c}\text { Depressive } \\
\text { symptom } \\
\text { positive } \\
\text { (HAM-D score } \\
\geq 8 \text { ) } \\
\text { (n:35, 52.2\%) }\end{array}$ & $\mathbf{p}$ \\
\hline Age (years)* & $50.46( \pm 15.82)$ & $57.25( \pm 17.45)$ & $0.099^{*}$ \\
\hline BMI $\left(\mathrm{kg} / \mathrm{m}^{2}\right)^{*}$ & $24.99( \pm 5.31)$ & $25.93( \pm 4.86)$ & $0.455^{*}$ \\
\hline $\begin{array}{l}\text { Dialysis time } \\
\text { (month) }^{\#}\end{array}$ & $42.57(18.20-91.27)$ & $\begin{array}{c}33.72 \\
(24.00-82.78)\end{array}$ & $0.935^{\mathrm{C}}$ \\
\hline $\mathrm{Kt} / \mathrm{V}^{\#}$ & $1.52(1.30-1.70)$ & $1.64(1.49-1.80)$ & $0.085^{\mathrm{C}}$ \\
\hline HAM-D score* & $4.06( \pm 2.11)^{\alpha}$ & $16.78( \pm 8.28)$ & $<0.001^{*}$ \\
\hline $\mathrm{MCCl}^{\#}$ & $4.00(3.00-6.00)^{\alpha}$ & $6.00(4.25-8.75)$ & $0.003^{\mathrm{C}}$ \\
\hline Creatinine $(\mathrm{mg} / \mathrm{dL}) *$ & $8.30( \pm 2.58)^{\alpha}$ & $7.01( \pm 1.85)$ & $0.022^{*}$ \\
\hline $\begin{array}{l}\text { Total cholesterol } \\
(\mathrm{mg} / \mathrm{dL})^{\#}\end{array}$ & $169(140-180)$ & $157(135-188)$ & $0.764^{\mathrm{C}}$ \\
\hline $\begin{array}{l}\text { BUN predialysis } \\
(\mathrm{mg} / \mathrm{dL})^{*}\end{array}$ & $63.19( \pm 15.68)$ & $60.10( \pm 14.79)$ & $0.411^{*}$ \\
\hline Hemoglobin $(\mathrm{g} / \mathrm{dL}) *$ & $11.42( \pm 1.13)$ & $11.08( \pm 1.18)$ & $0.243^{*}$ \\
\hline Albumin $(\mathrm{g} / \mathrm{dL})^{*}$ & $3.16( \pm 0.90)$ & $3.11( \pm 0.81)$ & $0.809^{*}$ \\
\hline iMA $(A B S U)^{\#}$ & $0.81(0.77-0.94)$ & $0.83(0.76-0.93)$ & $0.633^{\mathrm{C}}$ \\
\hline imA/AlbR $(\%)^{\#}$ & $25.45(20.51-33.12)$ & $\begin{array}{c}26.81 \\
(23.64-32.07)\end{array}$ & $0.688^{\mathrm{C}}$ \\
\hline Native thiol $(\mu \mathrm{mol} / \mathrm{L})^{*}$ & $308.2( \pm 55.3)$ & $298.6( \pm 55.5)$ & $0.480^{*}$ \\
\hline Total thiol $(\mu \mathrm{mol} / \mathrm{L})^{*}$ & $338.9( \pm 59.5)$ & $335.2( \pm 58.2)$ & $0.799^{*}$ \\
\hline Disulfide $(\mu \mathrm{mol} / \mathrm{L}) *$ & $15.35( \pm 5.96)^{\alpha}$ & $18.32( \pm 5.82)$ & $0.043^{*}$ \\
\hline $\begin{array}{l}\text { Disulfide/native thiol } \\
(\%)^{*}\end{array}$ & $5.04( \pm 1.95)^{\alpha}$ & $6.31( \pm 2.27)$ & $0.017^{*}$ \\
\hline $\begin{array}{l}\text { Disulfide/total thiol } \\
(\%)^{*}\end{array}$ & $4.53( \pm 1.62)^{\alpha}$ & $5.54( \pm 1.75)$ & $0.017^{*}$ \\
\hline $\begin{array}{l}\text { Native thiol/total thiol } \\
(\%)^{*}\end{array}$ & $90.9( \pm 3.2)^{\alpha}$ & $88.9( \pm 3.5)$ & $0.017^{*}$ \\
\hline \multicolumn{3}{|l|}{ Gender (F/M) ${ }^{\alpha}$} & $0.005^{\S}$ \\
\hline Female, n (\%) & $11(31.4)$ & $21(65.6)$ & \\
\hline Male, $\mathrm{n}(\%)$ & $24(68.6)$ & $11(34.4)$ & \\
\hline \multicolumn{3}{|c|}{ Education (under/graduate) } & $0.239^{\S}$ \\
\hline Undergraduate, $\mathrm{n}(\%)$ & $18(51.4)$ & $21(65.6)$ & \\
\hline Graduate, $\mathrm{n}(\%)$ & $17(48.6)$ & $11(34.4)$ & \\
\hline \multicolumn{3}{|c|}{ Status (not married/married) } & $0.437^{\S}$ \\
\hline Not married, $\mathrm{n}(\%)$ & $10(28.6)$ & $12(37.5)$ & \\
\hline Married, n (\%) & $25(71.4)$ & $20(62.5)$ & \\
\hline \multicolumn{3}{|l|}{ DM (no/yes) } & $0.439^{\S}$ \\
\hline No, n (\%) & $26(74.3)$ & $21(65.6)$ & \\
\hline Yes, n (\%) & $9(25.7)$ & $11(34.4)$ & \\
\hline \multicolumn{3}{|l|}{ HT (no/yes) } & $0.477^{\S}$ \\
\hline No, n (\%) & $20(57.1)$ & $21(65.6)$ & \\
\hline Yes, n (\%) & $15(42.9)$ & $11(34.4)$ & \\
\hline \multicolumn{4}{|c|}{$\begin{array}{l}\text { *Values are given as mean }( \pm s d),{ }^{*} \text { Values are given as Median }\left(I Q R:{ }^{1}{ }^{1} \text { th }\right. \\
\text { percentile-75th percentile), }{ }^{*} p \text {-value for Independent Samples Test. }{ }^{C} p \text {-value } \\
\text { for Mann-Whitney U Test, }{ }^{s} \text {-value for Chi-square Test, }{ }^{a} \text { Statistically } \\
\text { significantly different from the Non Depressive Symptom group, sd:Std. } \\
\text { Deviation, IQR: Interquartile Range. }\end{array}$} \\
\hline
\end{tabular}

Serum creatinine level was statistically and significantly lower in women $(6.93 \pm 1.53 \mathrm{mg} / \mathrm{dL})$ than men $(8.37 \pm 2.73 \mathrm{mg} / \mathrm{dL}, \mathrm{p}=$ $0.011)$. Women's Kt/V score of 1.74 (1.54-1.88) was found to be higher than men's score of 1.52 (1.28-1.60, $p<0.001)$. However, dialysis of both groups (Kt/N score $>1.2$ ) was at sufficient level. HAM-D score was statistically significantly higher in women (10.0, 6.3-17.8) than men (4.0, 2.0-11.0, $p$ $<0.001)$. While there were $21(65.6 \%)$ women having depression symptoms ( $D S, \geq 8$ ) according to HAM-D score, this rate was found to be statistically higher than men (11 people, $31.4 \%, p=$ 
0.005). $\mathrm{MCCl}$ was $6.0(5.0-8.8)$ in women and $4.0(3.0-6.0)$ in men; and this was found to be statistically higher in women than men $(p=0.001)$. Table I shows the demographic characteristics of the study group and the comparison of the variables by gender.

According to HAM-D score, the study group was examined by being divided into two groups as those with DS (HAM-D score of $\geq 8$ ) and those without DS (HAM-D score: $0-7$ ). There were 32 people $(47.8 \%)$ with DS and $35(52.2 \%)$ people without DS. While $65.6 \%$ of the DS group were female, $31.4 \%$ of the other group were females and there was a statistically significant difference between two groups in terms of gender $(p=0.005)$. In both groups, no statistically significant difference was found in age, BMI, dialysis duration, Kt/V score, total cholesterol, BUN before dialysis, hemoglobin level, albumin, IMA, IMA/AlbR, NT, TT parameters, education level, marital status, accompanying DM and HT frequency. Serum creatinine level was higher in the DS group $(8.30 \pm 2.57 \mathrm{mg} / \mathrm{dL})$ than the group without DS (7.01 $\pm 1.85 \mathrm{mg} / \mathrm{dL}, \mathrm{p}=0.022)$. $\mathrm{MCCl}$ was found to be statistically significantly higher in the DS group $(6.0,4.25-8.75)$ than the other group $(4.0,3.0-6.0, p=0.003)$. Disulfide $(18.32 \pm 5.82$ $\mu \mathrm{mol} / \mathrm{L})$, disulfide/NT\% (6.31 $\pm 2.27 \%$ ) and disulfide/TT\% (5.53 $\pm 1.75 \%$ ) levels in the DS group were found to be statistically significantly higher than the disulfide (15.35 $\pm 5.96 \mu \mathrm{mol} / \mathrm{L})$, disulfide/NT\% (5.04 $\pm 1.95 \%)$ and disulfide/TT\% (4.53 \pm 1.62 $\%)$ values in the group without DS ( $p=0.043,0.017$ and 0.017 , respectively). NT/TT\% was statistically and significantly lower in the DS group $(88.9 \pm 3.49 \%)$ than the other group $(90.9 \pm 3.2$ $\%, p=0.017$ ). Table II shows demographic characteristics of the study group and the comparison of the variables by the presence of depressionsymptoms.

In the correlation analysis of the sample group; age had a correlation with creatinin, BMI, HAM-D score and $\mathrm{MCCl}(r=-0.403, p=$ $0.001, r=0.517, p<0.001, r=0.279, p=0.022$ and $r=0.635, p$ $<0.001$, respectively), dialysis time had a correlation with Kt/N ( $r$ $=0.303, p=0.013)$, albumin had a correlation with NT and $T T(r=$ $0.387, p=0.001$ vs. $r=0.352, p=0.003$, respectively). IMA/AlbR had negative correlation with albumin, NT and $\Pi(r=-0.854, p$ $<0.001, r=-0.357, p=0.003$ and $r=-0.351, p=0.004$, respectively) and NT had a positive strong correlation with $\Pi \mathrm{T}(r=0.979$, $p<0.001$ ). No significant correlation was detected other than these parameters.

These results indicated that both DS frequency and severity and comorbidity index in HD patients were higher in women. When groups with and without DS were compared, TDH generally shifted towardsoxidation in the DSgroup.

\section{DISCUSSION}

In HD patients, psychiatric problems such as attention problems, social incompatibility, anxiety, agitation, depression and suicidal tendency are frequently seen in HD patients. Depression and anxiety are the most common psychiatric disorders in HD patients and their relatives.

Many accompanying conditions such as frequent hospitalisa- tion, chronic pain, sleep disorders, loss of sexual function, and uremia can trigger psychiatric problems in HD patients. ${ }^{9}$

According to Korean National Health and Nutrition Examination Survey (2013-2015), the most important determinant and cause (best predictor) of the suicidal idea among chronic diseases was calculated as CRF. The most common emotional response disorder experienced by HD patients is depression and its prevalence varies between 13-54\%. Depression was found to be a strong indicator of suicidal idea in HD patients with CRF. ${ }^{10}$ In their study, Joseph et al., found the depression frequency as $42 \%$ in HD patients. In addition, they found that the cognitive functions increased in these patients as their education and socioeconomic levels increased; and there was a negative correlation between dialysis duration and cognitive level. ${ }^{11}$ Epidemiological studies have reported that the lifelong depression prevalence is $21.3 \%$ in women and $12.7 \%$ in men. ${ }^{12}$ In the present study, depression symptoms were found in almost two-thirds of women receiving HD treatment $(65.6 \%)$ and one-third of men receiving HD treatment $(31.4 \%)$, and almost half of the whole study group with the rate of $47.8 \%$. These results, in accordance with the previous studies, indicate that DSs are seen more frequently in HD patients than in society.

The etiology of depression in dialysis patients has been still not fully clarified. Some previous studies claimed that there was a correlation between depression severity and nutrition in the HD patient group. ${ }^{13}$ Some researchers did not find any correlation between nutrition and depression symptoms. ${ }^{6}$ Some researchers even claimed that uremia and depression symptoms were seen together. ${ }^{2}$ However, in results of the present study, the authors did not find any difference between HD patients with and withoutDS in terms of nutrition-related parameters such as BMI, albumin, total cholesterol, pre-dialysis BUN, and hemoglobin. In addition, there was correlation between HAM-D score showing depression symptoms and nutrition-related parameters. In the present study, although there was a difference between gender and depression, no difference was found between gender and nutrition parameters. Moreover, in the present study, any correlation between depression severity and limited nutritional parameters in HD patients were not seen. These results divergefrom the claim that there is a correlation between depression severity and nutrition in HD patients. However, it is believed that further studies should be carried out inlargerseries.

Its fastand easy application and success in predicting mortality-morbidity helped $\mathrm{MCCl}$ to be used widely. ${ }^{14}$ In their study, Yavuz et al. found high $\mathrm{MCCl}$ in the DS group. ${ }^{6}$ Similarly, in the present study, $\mathrm{MCCl}$ was calculated as comorbidity index and found to be significantly higher in the DS group. However, any correlation between $\mathrm{MCCl}$ and HAM-D scores were not found by the authors.

Along with the change occurring in the $\mathrm{N}$ terminal during ischemia, cobalt binding capacity of albumin changes, and this new molecule formed is called as ischemia modified albumin 
(IMA). The formation of IMA is one of the earliest markers of ischemia. IMA is also used as an indicator of oxidative stress. Some changes that occur in albumin, forming a vast majority of the plasma protein pool, may cause functional changes and weakness in antioxidant defence systems formed by plasma proteins. There are studies on IMA level in psychiatric diseases. In their study, Karaaslan et al. determined that IMA values of major depression patients were statistically and significantly higher than the healthy controls. In addition, they found a positive correlation between high IMA and depression severity in the major depression group. ${ }^{15}$ In the present study, no statistically significant difference was found in IMA and IMA/AlbR parameters in terms of both gender, and whether or not there was DS. This might have been due to the sample group in this study, including patients with more moderate DS.

Abnormal thiol disulfide concentration is associated with many inflammatory diseases. Thiol groups are important intracellular and extracellular antioxidants. TDH is a determinant of oxidative stress. In many inflammatory diseases, oxidative stress mediators have increased due to increased pro-inflammatory cytokines. In HD patients, particularly antioxidant defence decreases due to the decreased thiols with plasma proteins. In the study conducted by Solak et al. with HD patients and CRF patients and control groups, they found that TDH changed in favour of oxidative stress, that is, increase in disulphide. The increase was the highest in HD group and then in CRF group. ${ }^{16}$ In the study by Ates et al., the mean NT, TT and disulfide levels were found to be significantly lower in chronic kidney patients compared to the control group. They did not find a significant difference between chronic kidney patients and control group in terms of disulfide/thiol, disulfide/total thiol and thiol/total thiol ratio. ${ }^{17}$ In the study conducted by Çoşkun et al. with chronic renal failure (CRF), CRF +DM and controls, TT and NT levels were found to be significantly different than the control group, but similar between the patient groups. With this result, they concluded that thiol levels were associated with oxidant status in CRF patients, but not associated with the progression of CRF. In CRF patients, presence ofDM did not affect thiol level. ${ }^{18}$

There are studies showing that oxidative stress increases in many psychiatric disorders such as schizophrenia and depression. Brain tissue is more susceptible to oxidative damage because of high oxygen consumption in the brain, high phospholipids that may be oxidised and the inability of neurons to be regenerated. In addition, oxidants can cause changes in the transport and functions of the neurotransmitter by reacting with membrane proteins and/or enzymes in CNS. It was suggested that this may cause symptoms-specific to psychiatric disorders. ${ }^{19,20}$

In the study conducted by Yildizoglu et al. with unipolar depression patients, they found that TDH in depression patients shifted in favour of oxidative status compared to the control group. ${ }^{19}$ In the study conducted by Baykan et al., women with major depression disease showed no significant difference between the groups in terms of serum $\Pi \mathrm{T}$ levels. It was deter- mined that serum NT and NT/TT ratios were higher in the patient group than the control group; while serum disulfide, disulfide/NT and Disulfide/TT ratios were significantly lower. They found various correlations between HAM-D score and thiol levels of the patients. ${ }^{12}$ In another study conducted by Sahin et al. with patients having general anxiety and panic disorder, TDH was found to increase in favour of disulfide compared to the control group. ${ }^{20}$

In the presentstudy, the authors did notfind a significant correlation between thiol levels and HAM-D score. The TT and NT levels were similar between the groups. Statistically and significantly, higher disulfide, disulfide/NT\% and disulfide/TT\% levels in the DS group compared to the group without DS was found by the authors. NT/TT\% was found to be statistically and significantly lower in the DS group. While the results of the present study are similar to some results of the previous studies, the authors could not find some statistical differences; and some results were found as completely different. Brain is more susceptible to oxidative damage due to its high oxygen consumption and relatively lower antioxidant defence systems. This may be the basis of the correlation between oxidative stress and psychiatric disorders. Similarly, the fact that TDH was found to increase in favour of oxidative status in the DS group in the present study supports this view. The authors think that further studies are needed to explain the difference in the literature.

\section{CONCLUSION}

One of the psychiatric problems, frequently seen in HD patients, is depression; and its etiology has not been still fully clarified. The dialysis team should closely observe dialysis patients for depression, and ensure that patients receive professional psychiatric support when necessary. According to results of the present study, at least moderate depression symptoms are seen in about half of HD patients, and this changes TDH in the oxidant direction. It is said that TDH deterioration in HD patients is important in depression etiology. Further studies are needed on the causes of this change.

\section{FUNDING:}

This study has been financially supported by the Coordinating Committee of Scientific Research Projects of Konya Training and Research Hospital, Konya, Turkey (Decision date: 13/12/2018, Decision No. 20/02).

\section{CONFLICT OF INTEREST:}

The authors declared no conflict of interest.

PATIENTS' CONSENT: Informed consents were obtained from all patients (oral and written).

\section{ETHICALAPPROVAL:}

The study was approved by the Ethics Advisory Committee of the Selcuk University (Decision date: 26/09/2018, Decision No. 2018/321).

\section{AUTHORS'CONTRIBUTION:}

All authors contributed to the study conception and design.

HK, YTG, MAB, IG, NŞ, ZB: Performed material preparation, data 
collection, and analyses were performed.

HK: Wrote the first draft of the manuscript.

All authors commented on previous versions of the manuscript; read and approved the final manuscript.

\section{REFERENCES}

1. Tsay SL, Healstead M. Self-care self-efficacy, depression, and quality of life among patients receiving hemodialysis in Taiwan. Int J Nurs Stud 2002; 39(3):245-51. doi: 10.1016/ s0020-7489(01)00030-x.

2. King-Wing Ma T, Kam-Tao Li P. Depression in dialysis patients. Nephrology (Carlton) 2016; 21(8):639-46. doi: 10.1111/nep.12742.

3. Baydoğan M, Dağ í. Hemodiyaliz hastalarındaki depresiflik düzeyinin yordanmasında kontrol odağı, öğrenilmiğ güçlülük ve sosyotropi-otonomi. Turk Psikiyatri Dergisi 2008; 19(1):19-28.

4. Biswas S, Chida AS, Rahman I. Redox modifications of protein-thiols: emerging roles in cell signaling. Biochem Pharmacol 2006; 71(5):551-64. doi: 10.1016/j.bcp.2005.

5. Akdemir A, Türkçapar MH, Orsel SD, Demirergi N, Dag I, Ozbay MH. Reliability and validity of the turkish version of the hamilton depression rating scale. Compr Psychiatry 2001; 42(2):161-5. doi: 10.1053/comp.2001.19756.

6. Yavuz YC, Biyik Z, Ozkul D, Abusoglu S, Eryavuz D, Dag M, et al. Association of depressive symptoms with $25(\mathrm{OH})$ vitamin $D$ in hemodialysis patients and effect of gender. Clin Exp Nephrol 2020; 24(1):63-72. doi: 10.1007/ s10157-019-01794-7.

7. Erel O, Neselioglu S. A novel and automated assay for thiol/disulphide homeostasis. Clin Biochem 2014; 47(18): 326-32. doi: 10.1016/j.clinbiochem.2014.09.026.

8. Bar-Or D, Lau E, Winkler JV. A novel assay for cobaltalbumin binding and its potential as a marker for myocardial ischemia-a preliminary report. J Emerg Med 2000; 19(4):311-5. doi: 10.1016/s0736-4679(00)00255-9.

9. Gerogianni G, Polikandrioti M, Babatsikou F, Zyga S, Alikari V, Vasilopoulos G, et al. Anxiety-depression of dialysis patients and their caregivers. Medicina (Kaunas) 2019; 55(5):168. doi: 10.3390/medicina55050168.

10. Jeon HO, Kim J, Kim O. Factors affecting depressive symptoms in employed hemodialysis patients with chronic renal failure. Psychol Health Med 2020; 25(8):940-9. doi: 10.1080/13548506.2019.1702218.
11. Joseph SJ, Bhandari SS, Dutta S. Cognitive Impairment and its Correlates in Chronic Kidney Disease Patients Undergoing Haemodialysis. J Evol Med Dent Sci 2019; 8(36):2818-22. doi: 10.14260/jemds/2019/611.

12. Baykan H, Durmaz O, Baykan Ö, Alýpýk M, Can MP, Karlýdere $T$, et al. Dynamic thiol/disulphide homeostasis as a novel oxidative stress marker in women with major depressive disorder. Anatolian J Psychiatry 2018; 19(2): 135-42.

13. Markaki AG, Charonitaki A, Psylinakis E, Dimitropoulakis P, Spyridaki A. Nutritional status in hemodialysis patients is inversely related to depression and introversion. Psychol Health Med 2019; 24(10):1213-9. doi: 10.1080/13548 506.2019.1612074.

14. Tikici D, Sadettin E, Tez M. Acil kolorektal cerrahi yapılan hastalarda mortaliteyi öngörmede amerikan anesteziyoloji derneği sınıflaması (ASA) ve charlson komorbidite indeksi (CCI)'nin karşılaştırılması. Turkish J Clin Laborat 2018; 9(3):162-5. doi.org/10.18663/tjcl.450882.

15. Karaaslan Ö, Hacımusalar Y, Amuk ÖC, Bal C. Evaluation of ischemia modified albumin levels in major depression patients. J Surg Med 2019; 3(8):557-60. doi.org/10. 28982/ josam.598200.

16. Solak I, Guney I, Mercan S, Erel O, Neselioglu S, Cetinkaya $\mathrm{CD}$, et al. Changes in thiol/disulfide homeostasis in patients with chronic kidney disease. Medicine 2020; 9(1):201-4. doi: 10.5455/medscience.2019.08.9168.

17. Ateş i, Özkayar N, Yılmaz FM, Bayrakçı N, Neşelioğlu S, Erel Ö, et al. Oxidative stress level in patients with chronic kidney disease. Ortadogu Med J Ortadogu Tip Dergisi 2018; 10(1).

18. Coşkun C, Emre HÖ, Gümüş A, Uzun S, Karadağ S, Behlül A, et al. Diyabetik ve diyabetik olmayan kronik böbrek yetmezliğinde dinamik tiyol disülfit homeostazı ve ileri protein oksidasyon ürünleri (AOPPs). Deneysel Tıp Araştırma Enstitüsü Dergisi 2016; 6(12):1-9.

19. Yıldızoğlu ÇA, Taş Hi. Evaluation of oxidative stress with thiol disulfide balance parameters in unipolar depression patients with and without mixed symptoms. Anatolian J Psychiatry 2020; 21(4):341-8. doi: 10.5455 / apd.66783.

20. Kabadayi Sahin E, Turan G, Neselioglu S, Can SS, Atagun MI. Thiol-disulphide homeostasis in patients with general anxiety disorder and panic disorder. Dusunen Adam J Psychiatry Neurol Sci 2019; 32(4):289. dol: 10.14744/ DAJPNS.2019.00042. 